\title{
PEDAGOGICAL PROMOTION OF PROFESSIONAL SELF-REALIZATION OF FUTURE TEACHERS OF PHILOLOGICAL SPECIALITIES
}

\author{
Kateryna Poseletska \\ Vinnytsia Mykhailo Kotsiubynskyi State Pedagogical University, Vinnytsia, Ukraine \\ Olena Ihnatova \\ Vinnytsia Mykhailo Kotsiubynskyi State Pedagogical University, Vinnytsia, Ukraine \\ Olena Kochenko \\ Vinnytsia Mykhailo Kotsiubynskyi State Pedagogical University, Vinnytsia, Ukraine \\ Yana Hapchuk \\ Vinnytsia Mykhailo Kotsiubynskyi State Pedagogical University, Vinnytsia, Ukraine
}

\begin{abstract}
In the world of rapid change, the concept of professional self-realization is becoming an essential development factor for professionals. Modern teachers of philological specialties should be not only masters in their field who have indispensable professional and methodological competencies but also be ready to provide all necessary services for the current generation, which agrees with the framework of the "New Ukrainian School". To correspond to the above-mentioned standards, a philology teacher must strive for self-development and self-improvement. The readiness of future teachers for professional self-realization is an integrated quality manifested in independent productive activity aimed at personal selfdevelopment and self-improvement. Based on theoretical research and practical experience, we have determined pedagogical conditions for the formation of readiness of future teachers of philological specialties for professional self-realization: 1) ensuring readiness for the professional self-realization of future teachers of philological specialties based on the acknowledgement of career prospects; 2) actualization of the acmeological component of the vocational training of future philologists; 3) phased inclusion of future philologists into the practically focused activity during their teaching practice. The effectiveness of these pedagogical conditions has been examined through carrying out the pedagogical experiment and a set of questionnaires and tests to define the level of readiness for professional selfrealization. As a result, we have developed a system of practical classes "I am a future professional" and corrective tutorials with future teachers of philological specialties and developed common psychological and pedagogical guidelines for supervising teaching practice.
\end{abstract}

Keywords: professional self-realization; pedagogical conditions of training for professional self-realization; future teachers of philological specialties; career prospects; practically focused activity. 


\section{Introduction}

Modernization of the Ukrainian system of education necessitates identification of new strategic and tactical guidelines for training future teachers. Preparation of students for the educational process overall and teaching in particular aim at revealing potential capabilities of future specialists.

Modern scholars approach the problem of professional self-realization in the context of the reformist trends of social progress.

According to the findings of the scientists (Antsyferova, 2006; Ionova, 2015; Milchevska, 2014; Romenets, 2006, etc.), a person's self-realization presupposes considerable self-improvement and is characterized by changes in the selfawareness of the social status and ways of interaction with the outside world.

The integration-activity approach to the theoretical analysis of the structure and content of professional self-realization of students is attracting increasing interest nowadays. In this regard, it is important to determine the motives of selfrealization (Leontiev, 2003); the pace of self-realization (Rean, 2004); the measures of self-realization (T. Titarenko, 2003); study the formation of a teacher's personality in the system of higher pedagogical education (Gurevich, 2010; Kan-Kalik, 1988). Finally, the research should address such issues as readiness of future teachers for self-education and professional self-development (Bech, 2003); professional training of future teachers of philological specialties (Ivanitskaya, 2014).

The specific character of philological specialties is manifested in the systemfunctional paradigm of thinking, emotionality, reflexivity, empathy, communicative expressiveness, and multiculturalism of the content component, which actualizes the need for the development of tolerance (N. Ivanitska, 2014).

Hence, acmeologization of the professional activity of philology teachers and development of their axiosphere are becoming strategically important tasks for the system of higher pedagogical education. Ultimately, philology teachers perform the functions of intercultural communication, organizing the process of mutual recognition and enrichment of cultures that transforms into the ability to teach language as a national-cultural phenomenon and form a national valuebased linguistic picture of the world. In the present contradictory conditions, philological specialties, through "communication" with multi-genre works of art, including folk treasures, significantly affect the spiritual enrichment of students. Therefore, the realization of the creative approach to the professional training of philology teachers gains special attention and involves strengthening the existential component of the professional activity, which attests to the high level of professional skills that can be achieved due to meaningful professional selfrealization. 
At present, it is necessary to address from a practical scientific perspective a range of topical issues embodied in the following contradictions: between the recognition of the personal determinism of professional self-realization and the uncertainty of the components and criteria of future specialists' readiness for the practical realization of a professional plan; between the active use of the term "self-realization" and a significant variation in the definition of this concept; between the university teachers' awareness of the need to form the basis for professional self-realization and gaps in the corresponding organizational and methodological conditions; between the social demand for teachers of philological specialties capable of continuous professional self-realization and the inadequate level of its formation in graduates of pedagogical universities (Poseletska, 2016).

The aim of the article is to study the formation and the development of professional self-realization and to verify experimentally the pedagogical conditions for the professional self-realization of future teachers in the process of professional training. The study has the following objectives: 1 . To investigate the problem of preparing future teachers of philological specialties for professional self-realization at the interdisciplinary level; 2. To determine pedagogical conditions for the training of future teachers and their professional selfrealization; 3. To test the effectiveness of the implementation of the established pedagogical conditions for future teachers' self-realization in the process of professional training.

\section{Methods}

To accomplish the objectives of the research, the study employs the following methodology: a) theoretical methods: analysis, interdisciplinary synthesis, comparison; classification and systematization of theoretical data; b) empirical methods: diagnostic (questionnaires, interviews, psychological diagnostic techniques), observation; pedagogical experiment (ascertaining and formative experiments) to test the effectiveness of the pedagogical conditions for the training of future teachers with the purpose of professional self-realization; c) methods of mathematical statistics (using Student's t-test) for processing and evaluating the data validity of the results of the pedagogical experiment and determining the quantitative dependence between the phenomena under study.

The research encompassed three stages. At the organizational stage, we specified the conceptual apparatus of the research, developed the experimental program, and carried out the ascertaining experiment. The stage of the realization of the pedagogical conditions was devoted to conducting the formative experiment. During the generalization stage, we processed the results of the experiment and determined the efficiency of the pedagogical conditions. 
The formative experiment was conducted with 384 respondents: 17 teachers of higher educational establishments and 367 students of different pedagogical universities. As a result, the control group (CG) and the experimental group (EG) were formed, with 243 respondents being in the control group (CG) and 124 respondents - in the experimental one (EG).

Theoretical research and practical experience helped us to determine the pedagogical conditions for the professional training of future teachers of philological specialties. They ensured readiness for the professional selfrealization of future teachers of philological specialties based on the acknowledgement of career prospects (the effectiveness of the self-realization process relates to the success of the pedagogical activity of students during their teaching practice and positive future professional guidelines, which reveals potential career prospects); actualization of the acmeological component of the vocational training of future philologists (involves expanding the subject's personal space (active orientation, awareness, initiative, goal determination, inclusion in the activity, the desire for self-regulation, self-development, and selfrealization) and professional and moral enrichment, which implies increase of responsibility, sense of duty, conscience and honor, departure from inadequate personal settings and standards, which will stimulate the process of professional self-realization); phased inclusion of future philologists into the practically focused activity during their teaching practice (the ability of future philologists to realize the functions of the teaching practice indicates their readiness for professional self-realization.) (Poseletska, 2016).

To test the effectiveness of the pedagogical conditions through a pedagogical experiment, we distinguished three components in the structure of the professional training of future philologists. They are: motivational characterizes the incentive aspect of readiness and contains stable motives of professional self-realization, awareness of its importance, and the system of values and attitudes that encourage a person to realize his/her professional potential; emotional - characterizes the sensitive aspect of the readiness for professional self-realization, involves interiorization of professional values, a sense of responsibility for the results of pedagogical activity, self-control, and the ability to control the actions that affect the performance of professional duties of a teacher; activity - characterizes the practical aspect of readiness, providing skills for successful professional self-realization (the ability to assess, plan, organize, and control actions).

The criteria for determining the level of readiness for professional selfrealization were established based on the theoretical foundations of the study and in accordance with the developed structural model of readiness for professional self-realization. Each criterion was specified through indicators. The indicators of the motivational-value-based criterion are an ordered hierarchy of personal 
claims, systematic self-improvement, assessment of the subjective probability of success, and interiorization of professional values of future philologists; the emotional-volitional criterion is characterized by the following indicators: emotional stability, formation of a sense of responsibility for one's own professional actions, the ability to integrate the emotional efforts of participants in the educational process, and employing the methods of self-regulation and achievement of equal partnership; the indicators of the creative activity criterion are: the ability to use the time rationally within learning and cognitive and selfeducation activities, the ability to determine prospects of professional growth independently, and the ability to perform self-presentation and prevention of professional deformations, inducing students to discover their own literary and linguistic talents.

To check the level of the formation of these three components during the experiment, the following questionnaires and intelligence tests were used: 1) the motivational component - "Motivation of success and fear of failure" (questionnaire by A. Rean, 2004), test-questionnaire"Need for achievement", "Self-assessment of creative potential" (Fetiskin, 2005); the method of revealing the style of self-actualization; the method of diagnosing the readiness of future teachers for creative self-realization in professional activity; 2) the emotional component - Spielberg's method; emotional satisfaction with the professional choice made (questionnaire); the level of development of empathic predisposition and questionnaire by $\mathrm{H}$. Eysenck aimed at identifying typical behavior); 3) the activity component - the questionnaire research aimed at determining the attitude of students to conflicts and the choice of response in conflict situations (questionnaire modified by A. Batarshev,); determination of personal orientation; the hierarchical structure of students' values; identification of the formed ideas about the career growth of university students as a component of value-based orientations (questionnaire survey), and the method of detecting the complex of authority threat (Poseletska, 2016).

Based on the determined criteria and indicators, the levels of readiness of future teachers of philological specialties for professional self-realization are identified and characterized as high, sufficient, and basic.

\section{Results and Discussion}

To realize the first pedagogical condition, the students were given examples of outstanding teachers who have reached pedagogical excellence. The following methods were used: explanation, refutation, and involvement in discussions without moralization. After the diagnostic techniques had been conducted, their results were used as a foundation for the program of students' self-development. 
To realize the second pedagogical condition, we have developed and tested for three years the system of practical classes "I am a future professional" and the system of corrective tutorials with future teachers of philological specialties (30 hours). The overall purpose of the research was to expand the methods of pedagogical interaction with students by enhancing the mechanisms of their personal reflection and developing empathic predisposition.

The program of corrective tutorials is developed based on the subject-activity approach. The main idea is that an individual does not only modify the activity and improve its results but also changes him-/herself by reinterpreting his/her own experience. Another positive aspect of this approach is that future teachers of philological specialties unlock their potential with regard to acquiring knowledge and skills as well as take responsibility for their implementation during teaching practice.

The main idea of the program is to promote psychological and pedagogical preparation of future teachers of philological specialties for effective interaction with students as an indicator of successful self-realization.

The objectives of the program are to increase students' knowledge about the conditions of effective interaction in the educational process, to give students an opportunity to realize themselves as subjects of professional interaction, to form their adequate self-esteem, and to improve students' practical skills of implementing empathic abilities in the process of communication.

The content of the program reflects a sequence of stages aimed at improving the components of pedagogical interaction: cognitive, behavioral, and emotional. The conditions for the successful implementation of the program content presuppose students' active involvement into the proposed activity, corrective interference of the facilitator, and students' systemic self-analysis of their emotional state based on feedback and personal reflection.

A specific feature of corrective tutorials is the possibility to model the methods of interaction with further analysis and designation of more effective variants, self-realization, and immediate feedback as well as professional selfidentification in simulated conditions with the prospect of its testing during the teaching practice.

Each tutorial has a specific structure combining the following elements: introduction, when students tune into the studies, reduce anxiety and tension, and are stimulated to active work; explication - acquaintance with the scientific category and explanation of its essence and significance for the process of pedagogical interaction; practical part, which involves the development of skills and abilities; the final part embracing the analysis of the performed work, selfanalysis of participation in the proposed activities, and reflection about the emotional state. 
To expand the information component with regard to the essence and mechanisms of professional self-realization, we have developed a system of classes in English language practice, where the students were looking for their own ways of solving pedagogical tasks, modeling fragments of the lessons in which they independently and creatively solved the suggested problems and demonstrated their results with further analysis. For example, at home reading classes, the students analyzed personal and professional qualities of a teacher, which could contribute to his successful professional activity (based on The Excellent 11 by Ron Clark) (Clark, 2004).

The third pedagogical condition was realized in several stages: observation of the pedagogical process, modeling the fragments of pedagogical actions, practical realization of certain pedagogical goals, and creative use of innovative ideas in their own pedagogical activities (Poseletska, 2017).

The determined stages were realized under the conditions of clear organizational delimitation. However, from the intellectual-cognitive perspective, such clear-cut boundaries are not necessary, as thinking activity at one stage transforms into practical activity at the next stage. Thus, the ideas of problembased and innovative-creative learning with a focus on the development of students' creativity and integrity of teaching practice can be successfully implemented. We, therefore, claim that the identified stages of teaching practice can contribute to the formation of the need for professional self-improvement and professional self-realization in students. It is possible to realize this task through carrying out personal diagnostics and modeling variants of possible pedagogical influence based on the achievements of experienced teachers and students' first personal experience.

Further, we developed common psychological and pedagogical guidelines for supervising teaching practice and outlined the tasks for the emotional support of students. The latter include eliminating factors contributing to high levels of situational anxiety and excessive agitation in students; instilling confidence in them; displaying empathy, sincerity, and unconditional positive attitude towards students; while assessing students' professional behavior, focusing on its positive aspects and most effective manifestations; assisting students in overcoming psychological problems.

Thus, while preparing students for teaching practice, it is necessary to conduct psycho-propaedeutic activities: identifying and analysing anticipated challenges; holding individual and group consultations on specific aspects and objectives of teaching practice; inviting junior students to the final conferences on the teaching practice of senior students; organizing annual camps and giving lectures and practical classes to prevent possible difficulties ("How we can take into account the individual characteristics of each child in the classroom", "Methods of stimulating the cognitive activity of students in the classroom", 
"Conflict situations and ways of their prevention"); organizing active social and psychological training to boost students' self-esteem, develop skills of confident behavior, and reduce excessive anxiety before conducting a trial lesson (Poseletska, 2016).

During the experiment, the students reacted positively to the recommended algorithm of preparing for a trial lesson. According to this algorithm, students can reconstruct their preparation for a trial lesson, which will help outline specific tasks at the next stages of teaching practice, relieve excessive emotional stress, and positively influence their motivation for other professional activities, which will stimulate the need for students' professional self-realization.

In addition to submitting the reporting documentation at the end of their teaching practice, the students were asked to prepare a reflective diary where they were encouraged to express their feelings about the first teaching experience, with a focus on its ups and downs and recommendations for improving their activity.

The results of the research conducted within the forming stage of the experiment revealed that the developed and tested program directly impacted the students' professional self-realization and reinterpretation of individual codes of behavior in the situations of difficult communication.

During the generalization stage, we processed the results of the experiment and determined the efficiency of the pedagogical conditions by comparing the results of the experimental (EG) and control (CG) groups with the help of Student's $t$-test. The analysis of the results of the experiment revealed that the indicators of the levels of readiness for professional self-realization increased significantly in the EG, while in the CG, there was slight positive dynamics (Table 1). The differences between the groups are significant and constitute the value of $\mathrm{p} \leq 0.05$.

Table 1 Levels of readiness for professional self-realization of future philologists

\begin{tabular}{|c|c|c|c|c|}
\hline \multirow[t]{3}{*}{ Level } & \multicolumn{4}{|c|}{ Group } \\
\hline & \multicolumn{2}{|l|}{ CG } & \multicolumn{2}{|l|}{ EG } \\
\hline & Before & After & Before & After \\
\hline high & $6,0 \%$ & $8,3 \%$ & $6,8 \%$ & $15,4 \%$ \\
\hline sufficient & $42,8 \%$ & $44,4 \%$ & $44,7 \%$ & $54,1 \%$ \\
\hline basic & $51,2 \%$ & $47,3 \%$ & $48,5 \%$ & $30,5 \%$ \\
\hline
\end{tabular}

According to the results of the summary table (Table 1), it can be stated that after the experiment, the changes in the EG are more significant. Thus, high-level indicators in the CG increased by $2.3 \%$, and in the EG - by $8.6 \%$; correspondingly, the indicators of a sufficient level in the CG increased by $1,6 \%$, and in the EG - by 9,4\%; the basic level in the CG decreased by 3.9\%, and in the EG - by $18.0 \%$. 
Therefore, we can identify a generally positive tendency to changes in the EG due to the growth of the indicators of high and sufficient levels and, accordingly, the decrease of the indicators of the basic level. The results have confirmed our hypothesis that the training of future teachers of philological specialties for professional self-realization can be effective by implementing the identified pedagogical conditions.

Ukraine's modern educational space is characterized by rapid changes occurring due to conducting educational reforms as part of state policy. These transformations are mainly associated with the need to update the goals, content, and forms of learning as well as introduce innovative technologies into the educational process. Of equal importance is the preparation of a new generation teacher who would provide all the educational services necessary for the modern generation, which corresponds to the framework of the "New Ukrainian School". In this context, the most pressing issue is preparing future teachers of philological specialties who have indispensable professional and methodological competencies and are ready for self-development and self-improvement. The readiness of future teachers for professional self-realization is an integrated quality manifested in independent productive activity aimed at personal selfdevelopment and self-improvement. Hence, pedagogical educational institutions should promote professional self-realization of future teachers of philological specialties, which is possible under the above-mentioned pedagogical conditions that entail providing professional information, diagnosing and maintaining professional qualities of future teachers, developing empathic predisposition and expanding pedagogical interaction techniques as well as involving future philologists into practically oriented activities during teaching practice.

\section{Conclusions}

It can be stated that after the experiment, the changes in the EG are more significant. Thus, high-level indicators in the CG increased by $2.3 \%$, and in the EG - by 8.6\%; correspondingly, the indicators of a sufficient level in the CG increased by $1,6 \%$, and in the EG - by 9,4\%; the basic level in the CG decreased by $3.9 \%$, and in the EG - by $18.0 \%$.

Therefore, we can identify a generally positive tendency to changes in the EG due to the growth of the indicators of high and sufficient levels and, accordingly, the decrease of the indicators of the basic level. The results have confirmed our hypothesis that the training of future teachers of philological specialties for professional self-realization can be effective by implementing the identified pedagogical conditions.

The analysis of the quantitative and qualitative results of the experimental study testifies that the research aim, namely the substantiation of the pedagogical 
Poseletska et al., 2020. Pedagogical Promotion of Professional Self-Realization of Future Teachers of Philological Specialities

conditions for the training of future teachers of philological specialties for professional self-realization, has been achieved.

We have proven the efficiency of the identified pedagogical conditions and devised the methodology for developing readiness for professional selfrealization in future teachers of philological specialties. Further research should target an individual approach to training students for professional self-realization and the theoretical substantiation of the faculty's work with future teachers of philological specialties aimed at preparing them for professional self-realization.

\section{References}

Antsyferova, L.I. (2006). Razvitie lichnosti i problemy herontopsikholohii [Personal development and the problems of gerontopsychology]. Moscow: Institut psikhologii RAN.

Batarshev, A.V. (2007). Diagnostika professional no vazhnikh kachestv [Diagnostics of professionally important qualities]. Piter.

Bech, I.D. (2003). Vykhovannia osobystosti. Osobystisno-oriientovanyi pidkhid: naukovopraktychni zasady [Personal education. Person-centered approach: scientific and practical background]. Kyiv. Lybid.

Clark, R. (2004). The Excellent 11: qualities teachers and parents use to motivate, inspire and educate children. New York.

Fetiskin, N.P. (2005). Soczial `no-psikhologicheskaya diagnostika razvitiya lichnosti i maly kh grup [Socio-psychological diagnosis of personality development and small groups: a training manual]. Izdatel`stvo Instituta Psikhoterapii.

Guevich, R.S., Kademiia, M.Y., \& Shevchenko, L.S. (2010). Kompetentnisna osvita u vyshchii pedahohichnii shkoli. Vinyytsia [The competent education at higher education establishments]. Planer.

Ionova, I.M. (2015). Pedahohichni umovy tvorchoi samorealizatsii starshoklasnykiv u protsesi navchalnoi proektnoi diialnosti [Pedagogical conditions of creative self-realization of senior high school students in the process of learning project activity]. Extended abstract of candidate dissertation, Kharkiv National Pedagogical Skovoroda University, Kharkiv, Ukraine.

Ivanitskaya, N.L. (2014). Formuvannia ekolohichnoi kultury studentiv-filolohiv zasobamy ukrainskoho slova [The formation of ecological culture of students-philologists by means of Ukrainian word]. Suchasni informatsiini tekhnolohii ta innovatsiini metodyky navchannia $v$ pidhotovtsi fakhivtsiv: metodolohiia, teoriia, dosvid, problemy, 40, 259-263.

Kan-Kalik, V.A. (1988). Uchitelyu o pedagogicheskom obshhenii [To teacher about pedagogical communication]. Moscow. Prosveshhenie.

Leontiev, D.A. (2003). Samorealizatsiiai sushchnostnye sily cheloveka [Self-Realization and Essential Human Powers]. In Psychology with a Human Face: A Humanistic Perspective in Post-Soviet Psychology (156-175). Moscow.

Milchevska, H.S. (2014). Osobystisna samorealizatsiia starshoho pidlitka $v$ umovakh dytiachoho zakladu ozdorovlennia ta vidpochynku [Personal self-realization of a teenager in the children's camp environment]. Extended abstract of candidate dissertation, Kyiv National Pedagogical Dragomanov University, Kyiv, Ukraine. 
Poseletska, K.A. (2016). Pidhotovka maibutnikh uchyteliv filolohichnykh spetsialnostei do profesiinoi samorealizatsii [Training of future teachers of philological specialties for professional self-realization]. Published candidate dissertation, Vinnytsia Mykhailo Kotsiubynskyi State Pedagogical University, Vinnytsia, Ukraine. Retrieved January 11, 2019, from https://vspu.edu.ua/science/dis/d13.pdf

Poseletska, K.A. (2017). Praktychno-oriientovana diialnist maibutnikh uchyteliv filolohichnykh spetsialnostei v protsesi pedahohichnoi praktyky [Practically-oriented activities of future teachers of philological specialties in the process of teaching practice]. Pedahohichni nauky: teoriia, istoriia, innovatsiini tekhnolohii, 1, 116-126. DOI: 10.24139/2312-5993/2017.01/116-126.

Rean, A.A. (2004). Psikhologiya lichnosti. Soczializacziya, povedenie, obshhenie [Psychology of Personality. Socialization, behavior, communication]. Moscow. Prajm-EVROZNAK.

Romenets, V.A. (2006). Vchynok i postannia kanonichnoi psykholohii [The deed and the rise of canonical psychology]. Liudyna. Subiekt. Vchynok: Filosofsko-psykholohichni studii, 11-36.

Titarenko, T.M. (2003). Zhyttievi domahannia i profesiine stanovlennia osobystosti praktychnoho psykholoha [Life-long harassment and professional formation of the personality of a practical psychologist]. Praktychna psykholohiia ta sotsialna robota, 4, 15-18. 